TINJAUAN PUSTAKA

\title{
PERAN REKAM MEDIK GIGI SEBAGAI SARANA IDENTIFIKASI
}

\author{
Murniwati \\ Staf Fakultas Kedokteran Gigi Universitas Andalas \\ email : murniwatihabib@yahoo.com
}

\begin{abstract}
Abstrak
Indonesia merupakan salah satu negara yang rawan terjadi bencana. Metode identifikasi korban akibat bencana salah satunya melalui pencocokan dental record. Dental record yang dapat digunakan dalam proses identifikasi adalah yang sesuai dengan Standar Nasional Rekam Medik Kedokteran Gigi yaitu harus memuat data identitas pasien, keadaan umum pasien, odontogram, data perawatan kedokteran gigi serta nama dan tanda tangan dokter gigi dan harus diisi secara lengkap.

Kata Kunci : Dental Record, Standar Nasional Rekam Medik Kedokteran Gigi, Identifikasi Korban, Odontogram
\end{abstract}

\begin{abstract}
Indonesia is one of the disaster-prone countries. One method of identification of victims of the disaster is through matching dental records. Dental records that can be used in the identification process must comply with National Standard of Dentistry, Dental Record must contain data that identity of the patient, patient's general condition, odontogram, dental care data and the name and signature of the dentist and dental records are more important filled completely.

Key word : Dental Record, National Standard Medical Record Dentistry, Victim Identification, Odontogram
\end{abstract}




\section{PENDAHULUAN}

Secara geologis Indonesia terletak di pertemuan antara 3 lempeng tektonik utama dunia (Eurasia, IndoAustralia, Mediterania) sehingga Indonesia menjadi salah satu negara di dunia yang wilayah paling rentan terhadap berbagai bencana alam. Skala bencana alam yang biasa terjadi pun sering tergolong bencana besar yang memakan cukup banyak korban. Bencana merupakan kejadian yang mendadak, tidak terduga dapat terjadi pada siapa saja, dimana saja, kapan saja serta mengakibatkan kerusakan dan kerugian harta benda, korban manusia yang relatif besar baik mati maupun hidup. $^{(1,2)}$

Sumatra Barat khususnya kota Padang merupakan salah satu wilayah di Indonesia yang kondisi geologis dan geografisnya berada pada jalur gempa dan dekat pantai. Hal ini menyebabkan wilayahnya menjadi daerah yang memiliki potensi bencana cukup besar. Salah satu bencana gempa bumi yang terjadi September 2009, dimana korban yang ditemukan rata-rata mengalami kerusakan berat pada wajah dan sidik jari karena tertimpa bangunan, sehingga sulit untuk dilakukan identifikasi korban dengan sidik jari. Cara alternatif yang digunakan adalah identifikasi melalui gigi geligi dengan melakukan pencocokan dental records. Cara ini dilakukan dengan metode standar Internasioal yang ditetapkan oleh Interpol dan dibeberapa jurnal telah dikatakan bahwa metode identifikasi melalui gigi geligi ini terbukti cepat, akurat dan tidak memakan biaya yang besar terutama pada kasus yang memakan korban banyak dan keadaan korban yang telah mengalami kerusakan parah pada tubuhnya terutama wajah dan sidik jari. ${ }^{(1,3,4)}$
Identifikasi dengan sarana gigi dilakukan dengan cara membandingkan data gigi yang diperoleh dari pemeriksaan gigi jenazah yang tidak dikenal (data postmortem) dengan data gigi yang pernah dibuat sebelumnya dari orang yang diperkirakan (data antemortem). Identifikasi dengan cara membandingkan data ini akan dapat memberikan hasil identifikasi sampai tingkat individual, yaitu dapat menunjuk siapa orang yang diidentifikasi. Jadi data gigi berupa rekam medik gigi (dental record) yang pernah dibuat sebelumnya (data antemortem) merupakan syarat utama yang harus ada apabila identifikasi dengan cara membandingkan akan diterapkan. ${ }^{(5)}$

Rekam medik menurut UndangUndang No.29 tahun 2004 adalah berkas yang berisi catatan dan dokumen tentang identifikasi pasien, pemeriksaan, pengobatan, tindakan dan pelayanan lain yang telah diberikan kepada pasien. Rekam medik gigi minimal memuat: identitas pasien, pemeriksaan fisik intra oral dan ekstra oral yang dilengkapi dengan odontogram, diagnosis/masalah, tindakan/pengobatan, pelayanan lain yang diberikan kepada pasien dan pesetujuan atau informed concern.. ${ }^{(4)}$

Berdasarkan Pedoman Standar Nasional Rekam Medik Kedokteran Gigi Tahun 2007, data-data dalam blangko rekam medik adalah : Identitas Pasien, Keadaan Umum Pasien, Odontogram, Data Perawatan Kedokteran Gigi, Nama Dokter Gigi yang merawat.

Rekam medik gigi perlu disosialisasikan kepada masyarakat, agar setiap individu mempuyai catatan/rekam gigi (dental record) sehingga memudahkan bila diperlukan sebagai sarana komunikasi antar dokter gigi dalam proses identifikasi. Dengan demikian adanya medik gigi yang 
lengkap sesuai Standar Nasional Rekam Medik Kedokteran Gigi semakin terasa diperlukan. ${ }^{(2)}$

Pemerintah telah mengeluarkan berbagai kebijakan untuk mendukung dan mendorong diselenggarakannya rekam medis yang lengkap. Surat Keputusan Menteri Kesehatan No. 749a/Menkes/Per/XII/1989 menegaskan bahwa setiap sarana pelayanan kesehatan wajib membuat rekam medis, dan dilakukan oleh dokter/dokter gigi dan tenaga kesehatan lainnya yang memberikan pelayanan langsung ke pasien. $^{(6)}$

\section{Rekam Medis}

Berdasarkan Peraturan Mentri Kesehatan Republik Indonesia Nomor 269/Menkes/Per/III/2008 rekam medis adalah berkas yang berisikan catatan dan dokumen tentang identitas pasien, pemeriksaan, pengobatan, tindakan dan pelayanan lain kepada pasien. Departemen Kesehatan Republik Indonesia menyatakan bahwa rekam medis adalah keterangan baik yang tertulis/terekam tentang identitas pasien, anamnesa, penentuan fisik, laboratorium, diagnosa segala pelayanan dan tindakan yang diberikan kepada pasien dan pengobatan baik di rawat jalan, rawat inap, dan gawat darurat. Menurut Undang-Undang No.29 Tahun 2004 rekam medis adalah berkas yang berisikan catatan dan dokumen tentang identitas pasien, pemeriksaan, pengobatan, tindakan dan pelayanan lain yang telah diberikan kepada pasien.

Falsafah Rekam Medis menurut Departemen Kesehatan RI (1989) mencantumkan nilai-nilai aspek yang dikenal sebagai sebutan ALFREDS (Adsminitrative, Legal, Financial, Research, Education, Documentation and Service) yaitu sebagai berikut: ${ }^{(7)}$
1. Administrative (Aspek Adsministrasi)

Berkas rekam medis dikatakan mempunyai aspek administrasi, karena isinya menyangkut tindakan berdasarkan wewenang dan tanggung jawab sebagai tenaga medis dan paramedis dalam mencapai tujuan pelayanan kesehatan.

2. Legal (Aspek Hukum)

Berkas rekam medis mempunyai nilai hukum, karena isinya menyangkut masalah adanya jaminan kepastian hukum atas dasar keadilan, dalam rangka usaha menegakkan hukum serta penyedian bahan tanda bukti untuk menegakkan keadilan.

3. Financial (Aspek

Keuangan)

Berkas rekam medis mempunyai nilai uang, karena isinya mengandung data atau informasi yang dapat dipergunakan sebagai aspek keuangan.

4. Research (Aspek Penelitian)

Berkas rekam medis mempunyai nilai penelitian, karena isinya menyangkut data atau informasi yang dapat digunakan sebagai pengembangan ilmu pengetahuan dan penelitian di bidang kesehatan.

5. Education (Aspek Pendidikan)

Berkas rekan medis mempunyai nilai pendidikan, karena isinya menyangkut data atau informasi tentang perkembangan kronologis (terurut) dan kegiatan pelayan medik yang diberikan kepada pasien, informasi tersebut dipergunakan sebagai bahan referensi pengajaran bidang profesi pemakai. 
6. Documentation (Aspek Dokumentasi)

Berkas rekam medis mempunyai nilai dokumentasi, karena isinya menyangkut sumber ingatan yang harus didokumentasikan dan dipakai sebagai bahan pertanggung jawaban dan laporan rumah sakit.

7. $\quad$ Service (Aspek Medis)

Berkas rekam medis mempunyai nilai medis, karena catatan tersebut dipergunakan sebagai dasar untuk merencanakan pengobatan atau perawatan yang harus diberikan kepada seorang pasien.

Kegunaan rekam medis hanya akan mengandung nilai $A L F R E D S$ jika para praktisi kesehatan merekam segala urutan kegiatan dengan baik, cepat dan tepat. Kesadaran akan manfaat perekaman hasil kerja para praktisi kesehatan tersebut sangat penting bagi pasien, rumah sakit, praktisi kesehatan sendiri dan perkembangan ilmu pengetahuan yang secara global dapat dikatakan sebagai upaya mempertinggi peradaban manusia. Kegunaan rekam medis secara umum sesuai dengan Undang-Undang Dirjen Pelayan Medis Depkes RI dalam keputusan No. 78 tahun1991 adalah sebagai berikut :

1. Sebagai media komunikasi antara dokter/-dokter gigi dan tenaga ahli lainnya yang ikut ambil bagian di dalam memberikan pelayanan, pengobatan, perawatan kepada pasien. 2. Menyediakan data yang berguna bagi pengguna penelitian dan pendidikan.

3. Sebagai dasar untuk merencanakan pengobatan atau perawatan yang harus diberikan kepada pasien.
4. Sebagai bukti tertulis atas segala tindakan pelayanan, perkembangan penyakit dan pengobatan selama pasien berkunjung atau dirawat di RS.

5. Sebagai dasar yang berguna untuk analisis, penelitian, dan evaluasi terhadap kualitas pelayanan yang diberikan kepada pasien.

6. Melindungi kepentingan hukum bagi pasien, rumah sakit maupun dokter dan tenaga kesehatan lainnya.

7. Sebagai dasar dalam perhitungan pembayaran pelayanan medis pasien.

8. Menjadi sumber ingatan yang harus didokumentasikan, serta bahan pertanggung jawaban dan laporan.

Kepemilikan Rekam Medis menurut Peraturan Menteri Kesehatan Republik Indonesia Nomor 269/Menkes/Per/III/2008 adalah :

1. Berkas rekam medis milik sarana pelayanan kesehatan.

2. Isi rekam medis merupakan milik pasien.

3. Isi rekam medis sebagaiman dimaksud pada ayat (2) dalam bentuk ringkasan rekam medis.

4. Ringkasan rekam medis sebagaimana dimaksud pada ayat (3) dapat diberikan, dicatat, atau dicopy oleh pasien atau orang yang diberi kuasa atau atas persetujuan tertulis pasien atau keluarga pasien yang berhak untuk itu.

Rekam Medis mempunyai Aspek Medikolegal sebagai mana tercantum dalam UU RI No 29 tahun 2004 tentang Praktek Kedokteran/Kedokteran gigi Pasal 46 : 
1. Setiap dokter atau dokter gigi dalam menjalankan praktek kedokteran wajib membuat rekam medis.

2. Rekam medis sebagaimana yang dimaksud di atas harus dibuat segera dan dilengkapi setelah pasien menerima pelayanan.

3. Pembuatan rekam medis dilakukan melalui pencatatan dan dokumentasihasil pemeriksaan, pengobatan, tindakan dan pelayanan lain yang telah diberikan kepada pasien.

4. Setiap pencatatan ke dalam rekam medis harus dibubuhi nama, waktu dan tanda tangan dokter, dokter gigi atau tenaga kesehatan tertentu yang memberikan pelayanan langsung.

5. Dalam hal terjadinya kesalahan dalam melakukan pencatatan pada rekam medik dapat dilakukan pembetulan.

6. Pembetulan sebagaimana yang disebutkan di atas hanya dapat dilakukan dengan pencoretan tanpa menghilangkan catatan yang dibetulkan dan dibubuhi paraf dokter, dokter gigi dan tenaga kesehatan yang bersangkutan.

Selain itu aspek medikolegal juga tercantum dalam Peraturan Mentri Kesehatan RI No1419/MENKES/Per/X/2005 Pasal 16 dan Surat Keputusan Menteri Kesehatan No. 749a/Menkes/Per/XII/1989 :

1. Dokter dan Dokter Gigi dalam pelaksanaan praktek kedokteran wajib membuat rekam medis.

2. Rekam medis sebagaimana dimaksud pada ayat (1) dilaksanakan sesuai ketentuan perundangundangan.
3. Setiap sarana pelayanan kesehatan wajib membuat rekam medis, dan dilakukan oleh dokter, dokter gigi dan tenaga kesehatan lainnya yang memberikan pelayanan kepada pasien.

Apabila dokter dan dokter gigi tidak membuat rekam medis akan mendapat Sanksi sesuai UU RI No 29 Tahun 2004 pasal 79: dipidana dengan pidana kurungan paling lama 1 (satu) tahun atau paling banyak Rp. 50.000.000,- (lima puluh juta rupiah) untuk setiap dokter dan dokter gigi yang dengan sengaja tidak membuat rekam medis sebagaimana dimaksud dalam pasal 46 ayat (1). Selain itu juga ada Sanksi Administratif UU RI No 29 Tahun 2004 Pasal 69:

1) Keputusan Majelis Kehormatan Disiplin Kedokteran Indonesia mengikat dokter, dokter gigi dan Konsil Kedokteran Indonesia.

2) Keputusan sebagaimana dimaksud pada ayat (1) dapat berupa dinyatakan tidak bersalah atau pemberian sanksi disiplin.

3) Sanksi disiplin sebagaimana dimaksud pada ayat (2) dapat berupa:

1. Pemberian peringatan tertulis

2. Rekomendasi pencabutan surat tanda registrasi atau surat izin praktek

3. Kewajiban mengikuti pendidikan atau pelatihan di institusi pendidikan kedokteran atau kedokteran gigi.

Menurut standar nasional rekam medik kedokteran gigi, tujuan pembuatan rekam medik gigi diantaranya :

1. Sebagai catatan mengenai keadaan gigi dan keluhan pasien saat datang, diagnosa dan 
perawatan yang dilakukan pada setiap kunjungan.

2. Sebagai dasar untuk menentukan tindakan yang akan dilakukan pada kunjungan berikutnya.

3. Catatan sebagai sejarah penyakit, perawatan sebuah gigi, tindakan yang telah atau pernah dilakukan pada sebuah gigi, sehingga dapat membantu diagnosa dan rencana perawatan selanjutnya.

4. Catatan mengenai keadaan umum pasien yang perlu diperhatikan, yang perlu dipertimbangkan dalam keputusan perawatan/pengobatan.

5. Sebagai data resmi/legal untuk pertanggung jawaban dokter gigi atas segala tindakan perawatan dan pengobatan yang telah dilakukan.

6. Gambaran mengenai kondisi kesehatan gigi pasien secara keseluruhan.

7. Sebagai sumber data untuk keperluan identifikasi jika diperlukan.
Manfaat rekam medik gigi menurut pedoman Standar Nasional Rekam Medik Kedokteran Gigi adalah :

1. Sebagai data resmi/legal atas pertanggung jawaban dokter gigi mengenai tindakan perawatan dan pengobatan yang telah dilakukan untuk pasien.

2. Untuk menentukan diagnosa dan rencana perawatan.

3. Bermanfaat sebagai sumber data untuk keperluan identifikasi jika suatu saat diperlukan.

4. Penggunaan dental record hanya bermakna bila disimpan dengan benar oleh dokter gigi yang merawat.

Berdasarkan Pedoman Standar Nasional Rekam Medik Kedokteran Gigi, data-data penting yang perlu dicatat, dirangkum dalam blangko rekam medik adalah Identitas pasien, Keadaan umum pasien, Odontogram, Data perawatan kedokteran gigi, Nama dokter gigi yang merawat. 

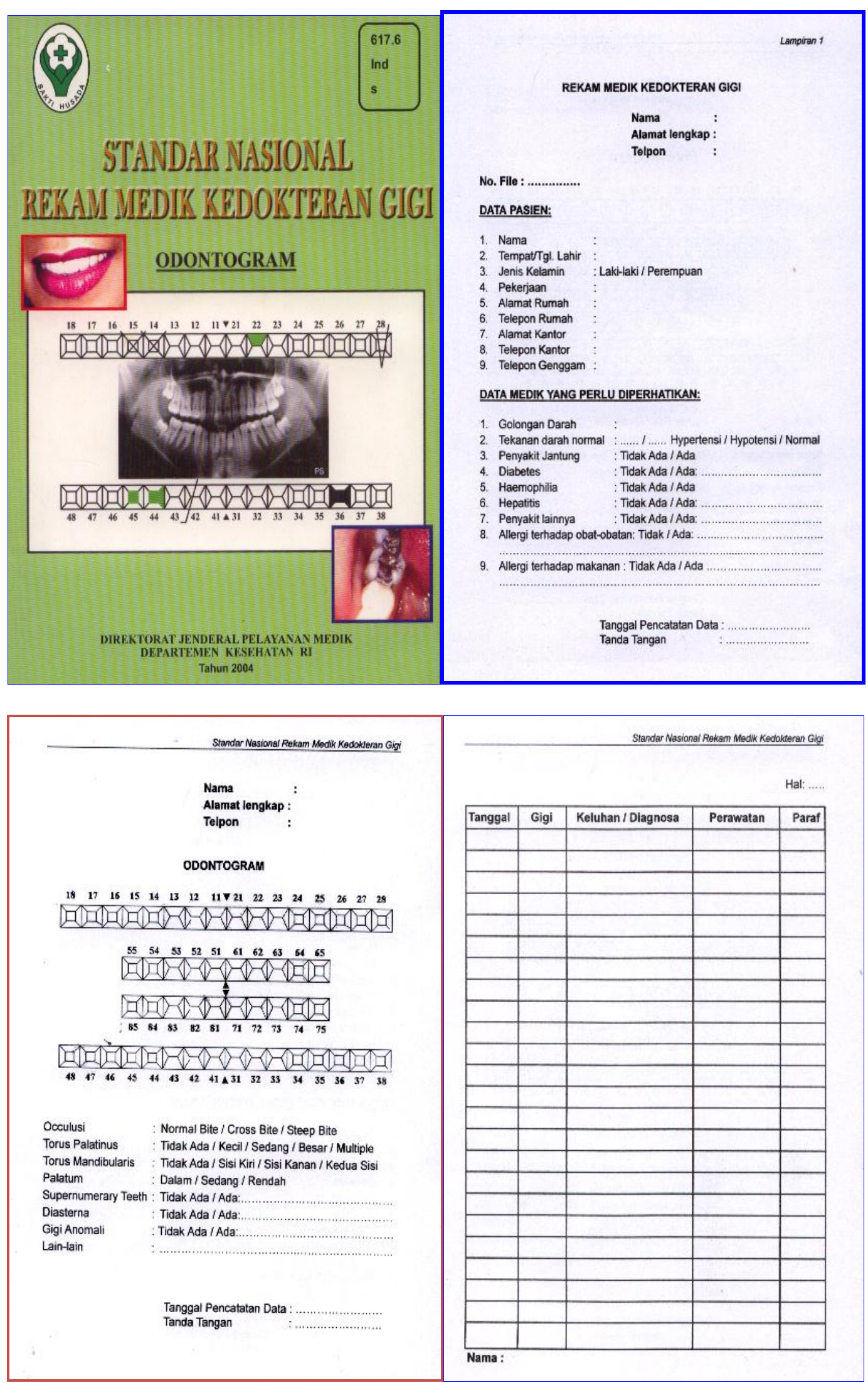

Gambar 1 : Contoh Rekam Medik Gigi yang sesuai dengan Standar Nasional Rekam Medik Kedokteran gigi 
1. Identitas Pasien.

Data identitas pasien cukup diisi sekali saja pada saat pasien pertama kali datang atau jika saat datang keluhannya perlu ditangani segera, cukup diisikan nama dan alamat saja, data lainnya dilengkapi sesegera mungkin pada kunjungan kedua. Data selalu disesuaikan jika ada perubahan seperti pindah alamat dan sebagainya.

Data identitas pasien dalam rekam data gigi minimal berisi:

1) Nomor file (administrasi dokter yang bersangkutan)

2) Tanggal pembukaan status

3) Nama

4) Jenis kelamin

5) Tempat dan tanggal lahir/umur

6) Alamat rumah, nomor telepon rumah dan handphone

7) Pekerjaan

8) Alamat kantor, nomor telepon kantor dan faximile

2. Keadaan umum pasien

Data keadaan umum pasien diperlukan sebagai catatan yang penting diperhatikan dalam melakukan tindakan yang berhubungan dengan kondisi medik pasien secara umum. Data ini sebaiknya diletakkan segera setelah identitas pasien agar segera terlihat oleh dokter sebelum merawat atau menuliskan resep.

Data keadaan umum pasien dalam rekam data gigi minimal berisi :

1) Golongan darah.

2) Tekanan darah normal (adakah kelainan tekanan darah).

3) Adakah kelainan hemophilia.

4) Adakah penyakit jantung.
5) Adakah penyakit diabetes.

6) Adakah alergi terhadap obat tertentu.

7) Adakah alergi terhadap makan tertentu.

8) Adakah penyakit-penyakit tertentu, seperti: hepatitis, HIV.

3. Odontogram

Pemerikasaan terhadap seluruh keadaan gigi dan mulut pasien dilakukan dan dicatatkan pada kunjungan pertama atau kesempatan pertama sehingga memberikan gambaran keadaan secara keseluruhan. Data ini di samping penting untuk membuat rencana perawatan kedokteran gigi secara menyeluruh juga sangat berharga sebagai data untuk keperluan identifikasi jika diperlukan sewaktu-waktu.

Odontogram selalu ditempatkan pada bagian awal dari lembar rekam medik gigi, setelah data identitas pasien dan data keadaan umum pasien. Selanjutnya baru diikuti lembar data perawatan kedokteran gigi yang dilakukan. Pembuatan odontogram diulangi atau dilengkapi : setiap satu tahun atau setiap kedatangan untuk kontrol atau jika pasien akan pindah kota/dokter gigi atau jika sebelum setahun sudah sangat banyak restorasi permanen yang dilakukan.

4. Data perawatan kedokteran gigi berisi:

1) Tanggal kunjungan.

2) Gigi yang dirawat.

3) Keluhan dan diagnosa.

4) Tindakan yang dilakukan.

5) Paraf dokter gigi (hal ini penting terutama jika yang mengerjakan tidak hanya satu dokter gigi). 
6) Rontgen foto, intra oral Dental record Sebagai Sarana digital foto jika ada.

\section{Identifikasi}

Pemeriksaan data gigi dilakukan Data gigi sangat bernilai untuk oleh setiap dokter gigi untuk identifikasi karena kemungkinan dua masing-masing pasien. Jika pasien orang mempunyai data gigi dan mulut memerlukan rekam data gigi, maka yang identik sangat kecil (1 berbanding kepadanya hanya dapat diberikan 2 milyar). Gigi merupakan bahan copy atau salinan data tersebut terkeras dari tubuh manusia yang untuk keperluannya dan data asli berkomposisi bahan organik dan airnya harus disimpan dokter gigi untuk sedikit sekali. Sebagian besar terdiri kepentingan masa depan, paling dari bahan anorganik sehingga tidak sedikit selama lima tahun setelah mudah rusak. Data rekam medik gigi ini pasien datang terakhir kalinya merupakan data minimal dari penderita kepada dokter gigi tersebut.

Nomenklatur Gigi dan Odontogram disarankan menggunakan 2 digit dari FDI (Federation Dentaire Internationale) / Interpol (International Police)..

1. Sistem FDI (Sistem 2 digit)

yang harus dicatat oleh dokter gigi. ${ }^{(4)}$

Gigi adalah bagian terkeras dari tubuh manusia yang komposisi bahan organik dan airnya sedikit sekali, sebagian besar terdiri dari bahan anorganik sehingga tidak mudah rusak, terletak di dalam rongga mulut yang terlindung dan basah oleh air liur. Gigi permanen, rahang dibagi menjadi 4 kuadran : Menurut Scott:gigi menjadi abu pada $1000^{\circ} \mathrm{F}-1200^{\circ} \mathrm{F}\left(538^{\circ} \mathrm{C}-649^{\circ} \mathrm{C}\right)$.

1) Angka 1, untuk Manusia mempunyai 32 gigi dengan rahang atas kanan. bentuk yang jelas dan masing-masing 2) Angka 2, untuk mempunyai 5 permukaan, berarti dalam rahang atas kiri mulut ada 160 permukaan gigi dengan 3) Angka 3, untuk variasi keadaan mulai baik, rusak, rahang bawah kiri. penambalan, pencabutan, gigi palsu, 4) Angka 4, untuk implant, dll. Penelitian Fernes (1972) rahang bawah kanan.

Pada tiap kuadran gigi diberi angka 1 sampai 8 untuk gigi permanen.

Gigi sulung,dibagi menjadi 4 kuadran :

1) Angka 5, untuk rahang atas kanan.

2) Angka 6, untuk rahang atas kiri.

3) Angka 7, untuk rahang bawah kiri.

menyatakan bahwa kemungkinan 2 orang identik data gigi dan mulutnya 1 berbanding 2 milyar penduduk, dengan perkiraan penduduk dunia 5 milyar, hampir mustahil ada 2 orang yang identik giginya.

4) Angka 8, untuk rahang bawah kanan.

Gigi diberi angka 1 sampai 5 untuk gigi sulung. ${ }^{(1)}$

Berbagai Informasi yang dapat diperoleh dari gigi diantaranya umur, ras, jenis kelamin, golongan darah, ciriciri khas, dan bentuk wajah/ raut muka korban.

\section{Kesimpulan}

Dental Record merupakan salah satu sarana yang digunakan untuk mengidentifikasi korban terutama pada korban bencana masal yang kondisi korban sulit dikenali secara visual dan 
mengunakan sidik jari sehingga perlu digunakan metode pemeriksaan gigi geligi yang sesuai Dental Record Standar Nasional Kedokteran Gigi. Gigi dengan sifat individualistic dan bahannya yang tidak mudah rusak dapat dipergunakan untuk memperkirakan umur, jenis kelamin, golongan darah, DNA, ras, bentuk wajah dan ciri-ciri khusus lainnya.

Dokter gigi sebagai pemberi pelayanan kesehatan gigi wajib membuat dan mengisi Dental Record dengan lengkap dan benar sebagaimanan ditetapkan dalam Peraturan Mentri Kesehatan RI No 1419/Menkes/X/2005 pasal 16. Data perawatan dapat digunakan dalam mengidentifikasi seorang. Sehingga pengisian Dental Record dengan benar akan sangat bermamfaat pada saatnya bila dibutuhkan sebagai data Ante Mortem.

\section{KEPUSTAKAAN}

1. Haris, M. 2009. Perangkat Lunak Untuk Proses Identfikasi. FASILKOM UI.

2. Direktorat Jendral Bina Pelayanan Medik Departemen Kesehatan RI. 2007. Standar Nasional Rekam Medik Kedokteran Gigi. Departemen Kesehatan RI Cetakan II.Jakarta.

3. Dinas Kesehatan Kota. 2011. Profil Kesehatan Kota tahun 2010 Edisi 2011. Dinas Kesehatan Kota Padang.

4. Fauzi, A. 2010. Pentingnya Dental record. Seminar Nasional PDGI Cabang Padang.
5. Sara, A. 1999. Peran Odontologi Forensik Sebagai Salah Satu Sarana Pemeriksaan Identifikasi Jenazah Tak Dikenal. Bagian Ilmu Kedokteran Forensik Fakulkas Kedokteran Universitas Gajah Mada. Yogyakarta.

6. Salami. 2008. Hubungan Pengetahuan dan Motivasi Dengan Perilaku Dokter Gigi Spesialis Dalam Pengisian Rekam Medis Di Badan Pelayanan Kesehatan Rumah Sakit Umum Sigli. Sekolah Pascasarjana Universita Sumatra Utara. Medan.

7. Departemen Kesehatan RI. 1989. Peraturan Menteri Kesehatan

No.749a/Men.Kes/Per/XIII/1989

Tentang Rekam Medis/Medical Record. Jakarta.

8. Pirngandi. 2008. Penatalaksanaan korban mati akibat bencana massal. Majalah Kedokteran Nusantara Volume 41 No 4 Desember 2008.

9. Satyo, A. 2006. Identifikasi Korban Post Mortem yang Dipatikan oleh Laporan Ante Mortem. Majalah Kedokteran Nusantara Volume 39.

10. Singh, S. 2008. Instansi/SMF Kedokteran Forensik dan Medikolegal Rumah Sakit Umum Dr. Pirngadi Medan. Majalah Kedokteran Nusantara Volume 41. 